\title{
Traumatic Shock
}

National Cancer Institute

\section{Source}

National Cancer Institute. Traumatic Shock. NCI Thesaurus. Code C50782.

Any shock produced by trauma. 